\title{
Total Respiratory System Resistance
}

National Cancer Institute

\section{Source}

National Cancer Institute. Total Respiratory System Resistance. NCI Thesaurus. Code C122185.

A calculated value based on all factors that influence the flow of gas from the airway opening to the alveoli, including airway resistance, and tissue resistance of the lung and chest wall. 